\title{
Building local institutions for national conservation programs: lessons for developing Reducing Emissions from Deforestation and Forest Degradation $(\mathrm{REDD}+)$ programs
}

\author{
$\underline{\text { Wain Collen }}^{1,2}$, Torsten Krause $^{3}$, Luis Mundaca $^{1}$ and Kimberly A. Nicholas $^{3}$
}

\begin{abstract}
For programs that aim to promote forest conservation and poverty alleviation, such as Reducing Emissions from Deforestation and Forest Degradation (REDD+), the participation of indigenous communities is essential to meet program goals. Using Ostrom's theory of collective action for common pool resource management, we evaluated the institutions governing indigenous participation in the Programa Socio Bosque incentive-based conservation program in Ecuador. We conducted structured interviews with 94 members in 4 communities to assess community institutions for 6 of Ostrom's principles, using 12 measures we developed for the principles. We found substantial variation between communities in terms of their institutional performance. The best-performing community performed well ( $>50 \%$ of interviewees reported successfully meeting the measure) on 8 of the 12 measures. The weakest performed well on only 2 out of 12 measures. Overall, our results indicate that there is stronger performance for constitutional-level institutions, which determine who gets to make the rules, and some collective-choice institutions, which determine how local rules are made. We identified specific challenges with the day-to-day operational institutions that arise from participation in nation statecommunity conservation programs, such as restricted resource appropriation, monitoring and compliance, and conflict resolution. We found that top-down policy making has an important role to play in supporting communities to establish constitutional-level and some collective-choice institutions. However, developing operational institutions may take more time and depend on local families' day-today use of resources, and thus may require a more nuanced policy approach. As some countries and donors find a jurisdictional REDD+ approach increasingly attractive, complementing top-down policy measures with bottom-up institutional development could provide a stronger platform to achieve the shift from current land use driving deforestation to a lower-carbon-emissions land management trajectory.
\end{abstract}

Key Words: Amazon; common pool resource (CPR); forest governance; forest policy; Socio Bosque

\section{INTRODUCTION}

Agriculture, forestry, and other land-use changes contribute $24 \%$ of global anthropogenic greenhouse gases, the largest share of any single economic sector (IPCC 2014). Therefore, reducing emissions from land-use change represents a significant climate change mitigation option. One approach to doing so emerged in 2005, when Papua New Guinea and Costa Rica first proposed the Reducing Emissions from Deforestation and Forest Degradation (REDD) program to the United Nations Framework Convention on Climate Change (UNFCCC; Babon and Gowae 2013). This was later extended under REDD+ to include conserving and enhancing forest carbon stocks and sustainably managing forests (Pistorius 2012). REDD+ is therefore a global environmental governance mechanism with the objective to slow and eventually halt deforestation and forest degradation from land-use change in developing countries by providing an economic incentive to keep carbon stored in vegetation and soils (Angelsen and Wertz-Kanounnikoff 2008, Skutsch and Van Laake 2008, Angelsen and Brockhaus 2009, Parker et al. 2009). Eliash (2008) estimates that global REDD+ investments will be in the proximity of US\$30 billion by 2020 , under three principal multilateral funding initiatives: the United Nations Collaborative Initiative on Reducing Emissions from Deforestation and forest Degradation (UN-REDD) program, the Forest Carbon Partnership Facility, and the Forest Investment Program.
Despite challenges at the UNFCCC to finalize a global REDD+ mechanism, the negotiations have been considered successful relative to other working areas of the UNFCCC (Grubb 2011). High-level discussions have triggered important developments in the global forest policy sector, including the implementation of REDD+ preparation activities at all policy levels (Pistorius 2012). Ecuador has responded actively, with the government demonstrating its commitment in line with REDD+ principles by making reducing deforestation a priority in the national development plan (SENPLADES 2008). Around 38\% of the country's land area is covered by forest, mainly Amazonian tropical forest (Bertzky et al. 2010). However, Ecuador maintains high levels of deforestation compared with other Latin American countries (Mosandl et al. 2008, FAO 2009, MAE 2011). High levels of deforestation and political will to reverse these trends make Ecuador a candidate that could benefit from the implementation of REDD+ activities (Da Fonseca et al. 2007). Working closely with the UN-REDD program since March 2011, Ecuador has been establishing the institutional, technical, and policy capacity (REDD+ Readiness) necessary for the implementation of REDD+ activities. Beginning in 2013, the Ministry of Environment has been steadily publishing legal norms that will regulate the future implementation of REDD+ in Ecuador, including a National REDD+ Program (PNREDD+) and Action Plan, a National Forest Monitoring System, and a Safeguard Information System (MAE 2013a, $2013 b, 2014 a$ ).

${ }^{1}$ International Institute for Industrial Environmental Economics (IIIEE), Lund University, ${ }^{2}$ PlanJunto, ${ }^{3}$ Lund University Centre for Sustainability Studies 
An important component of Ecuador's REDD+ program is a national-level pilot program for incentive-based conservation created in September 2008 called Programa Socio Bosque (Socio Bosque). Although Socio Bosque is not strictly a REDD+ project, primarily because it does not systematically target or monitor additional greenhouse gas emission reductions, the program is designed along similar principles. Socio Bosque provides an economic incentive for individual and collective landowners (e.g., indigenous communities with collective land titles) who agree to conserve native ecosystems on their lands for a period of 20 years. Socio Bosque aims to preserve around 3,600,000 hectares of native ecosystems such as Andean grasslands and tropical forest, and improve the lives of around 1 million people in rural areas (MAE 2009). Signing the Socio Bosque agreement requires that the established conservation area's natural vegetation cover is maintained and not altered by logging or conversion to agriculture. In case of noncompliance with program rules, sanctions can be imposed, such as the suspension of the next incentive disbursement (MAE 2009, MAE 2012). Socio Bosque has become a key element of Ecuador's REDD-iness preparation, specifically for incorporating local lessons from the ground into future national REDD+ policy and as a potential recipient of REDD+ funds (USAID 2012).

Since implementation, Socio Bosque has grown rapidly. As of December 2014, the program had more than 173,233 beneficiaries and had enrolled over 1.4 million hectares of forested land (MAE 2014b). Figures in 2013 showed that $95 \%$ of all program beneficiaries are from communal contracts, and more than $85 \%$ of all land included in Socio Bosque is collectively owned (MAE 2015a). More than $80 \%$ of the land under contract in Socio Bosque is tropical rain forest (MAE 2014b), and in this study we focused on four indigenous communities in the Ecuadorian Amazon.

\section{Indigenous participation in REDD+}

The participation of indigenous communities is a key factor for successful REDD+ outcomes (ITTO 2010, Cronkleton et al. 2011, FAO 2011, UN-REDD 2012). As in Socio Bosque, large parts of the tropical forests that REDD+ aims to protect are inhabited by indigenous communities (Sunderlin et al. 2008, Ricketts et al. 2010, Van Dam 2011), and traditional indigenous territories coincide with areas that encompass $80 \%$ of the world's biodiversity (Sobrevila 2008). Under these circumstances, the long-term effectiveness of REDD+ will depend on local communities managing their forest resources sustainably to achieve REDD+ goals (Cronkleton et al. 2011). However, relatively little attention and analysis have been given to locallevel processes and structures that will determine the effective implementation of REDD+ activities on the ground (Minang et al. 2014). As a result, there are some uncertainties at both the practical and political levels on how to achieve full and effective indigenous participation in REDD+ (Shankland and Hasenclever 2011). This may present later challenges for countries like Ecuador that are moving ahead with policy design to guide REDD+ implementation on large areas of territory collectively owned by indigenous populations, which require a shift from a status quo that is associated with deforestation to a lower-carbonemissions land management trajectory (Minang et al. 2014).

Previous research suggests that there are some challenges regarding local community participation in Socio Bosque (IRG
2010, Rojas et al. 2011, Krause et al. 2013), but researchers have been limited in terms of identifying the underlying causes of these local-level problems. In this paper, we focus on the governance institutions in four indigenous communities in the Ecuadorian Amazon participating in Socio Bosque. By applying an institutional lens, we aim to investigate the role of local institutions in supporting REDD+ goals and the potential for the enabling environment to foster strong local institutions that support forest conservation.

\section{METHODS}

\section{Analytical framework: local institutions for REDD+}

We used Ostrom's (1990) theory of collective action for common pool resource (CPR) management to analyze the local institutions governing forest conservation by indigenous communities in Socio Bosque. The theory originally described eight principles that characterize the institutional governance structures in systems that have achieved the sustainable management of CPRs, like tropical forests. We see the design principles as important elements reflecting the institutions required to achieve a robust management structure, which in turn is more likely to promote sustainable management of communal forest resources.

We extended Ostrom's original theory, developed in standard CPR systems such as irrigation systems and fisheries, to apply to the REDD+ case, which represents a type of contractual Payment for Ecosystems Services. The extension is relevant because tropical forest systems inhabited by indigenous populations can be classified as CPRs characterized by "excludability" and "subtractability," qualities that the four communities we investigated display. Excludability refers to the capacity of local users to exclude other users, i.e., neighboring communities, from entering or extracting from the resource. Subtractability means that when one person extracts resources, e.g., game or timber, from the resource pool, there is less available for others.

In all four communities in this study, land is collectively owned and thus belongs to all registered community members. These communities have registered forest areas for conservation under the Socio Bosque contract that also fall into the category of communal property: areas within the legal land title owned collectively by the community members, but not subdivided between families. These are large areas of land, ranging from 1000 to 10,000 hectares, which would require substantial effort to continuously monitor so that others are restricted from entering or extracting resources. The contractual obligation with Socio Bosque introduces an economic benefit for the community as a whole, as long as the community follows the rules to not extract timber, hunt for commercial purposes, or plant crops in the Socio Bosque area. As in a CPR system, community members benefit from coordinating their actions to conserve large forest areas to receive the Socio Bosque incentive payment. Within this context, lessons on the importance of local institutions for sustainable management of communally owned resources are relevant to how communities adjust land-use behavior away from deforestation activities, in line with REDD+ climate change mitigation goals.

Ostrom (1999) identified eight principles that characterize sustainable CPR management systems, which are underpinned by robust local governance institutions that are supported by an external enabling environment. Here, institutions refer to the formal and informal rules of the game that govern human 
behavior and interaction (North 1990), whereas the enabling environment is composed of the policies, laws, and governance processes in which the local system is situated (Dongier et al. 2003).

Ostrom divides the eight principles into three levels: operational, collective choice, and constitutional. Operational rules are those that govern day-to-day activities that directly affect the physical world, such as resource appropriation, monitoring, and enforcement. For example, these rules may describe when, where, and how resources may or may not be withdrawn from the CPR system. Collective-choice rules refer to the rules used in making the operational rules, i.e., how operational rules are made. Thus, changes in the operational level have to come from the collectivechoice level. For example, if a community decides that an assembly will be held to review operational rules twice a year and should be attended by a majority of community members, that would be a collective-choice rule. At the third level, constitutionallevel rules over common property define who is eligible to govern; these may also be understood as the rules that are used to craft collective-choice rules. Changes in the collective-choice level have to come from the constitutional level. Rules at the operational level tend to be easier to change than rules at the collective-choice level, and constitutional-level rules are usually the most difficult to change. Furthermore, different rules may function as intended to differing degrees. Ostrom thus refers to working rules as "those actually used, monitored and enforced" (Ostrom 1990:51).

Although managing CPRs sustainably is an "uncertain and complex undertaking" (Ostrom 1990:33), under the right conditions many communities do manage communal resources sustainably, largely through the development of effective institutions (Ostrom 1990, Baland and Platteau 2000, Chhatre and Agrawal 2008). It is important to bear in mind that some communities are more successful than others at establishing these institutional structures (Ambika and Ganesh 2006, Chhatre and Agrawal 2008). Without attending to the questions of how institutions for sustainable management of community-owned forests develop and how the enabling environment can support or undermine this process, policies for conservation through community-based organizations risk failure (Meinzen-Dick et al. 2004).

\section{Operationalizing Ostrom's design principles for local institutions}

We applied the first six of Ostrom's design principles as a framework for analysis of local institutions in the participating communities. We did not include the seventh principle in the framework because it looks at the enabling environment, and our framework focuses on local institutions. However, we do discuss the enabling environment in detail in the Discussion section. For uniformity, we did not assess the eighth principle, which applies to federated systems, because only one of our four communities had some form of federated structure.

A summary of the design principles for CPRs as described by Ostrom $(1990,1999,2009)$ and how they apply for community forest conservation in Socio Bosque follows:

1. Clearly defined boundaries. The first principle has two levels. First, boundaries are established for the resource users who have the right to enter, harvest, manage, and potentially exclude others from the resource system. If these rules are not well defined, then it is not clear who may and who may not benefit from the payments for conservation system. On the second level, communities need to clearly define the boundaries of the conservation system itself.

2. Congruence. The second principle also consists of two levels. Firstly, the rules that are being used to govern the forest resource system should balance the costs and benefits of doing so. If communities feel that the forest conservation rules do not allocate benefits proportional to costs, then the rules will lose legitimacy and it is less likely that most users will continue to follow the rules. Secondly, rules should be well aligned with the local governance conditions and norms of the area, because if forest conservation rules are not congruent with local conditions they risk not being accepted by those affected. (Ostrom's second principle also assesses congruence with local ecological conditions; however, this falls beyond the scope of this paper because we focus on the social governance conditions).

3. Collective-choice arrangements. The third principle is that those affected by the resource management rules are also those that make and modify the rules that govern the resource system. Community forest conservation systems that comply with this principle are likely to have rules in place that are suitable to local conditions and considered fair by those affected.

4. Active monitoring. The fourth principle is that monitors, who are either the users themselves or are accountable to users, actively audit the resource system conditions. Communities who manage their forests in line with rules assign monitors from within the group, and these monitors report back regularly to the users.

5. Graduated sanctions. The fifth principle is that communities develop a set of sanctions that are applied according to the seriousness of the noncompliance. This reflects careful consideration, application, and adaptation of the forest conservation rules to suit the severity of infringements.

6. Conflict resolution mechanisms. The sixth principle is that there are rapid, low-cost arenas to deal with conflicts among users or between users and officials. Simple, local mechanisms to air and solve conflicts related to the area under conservation help maintain trust and cooperation among users.

As described earlier, Ostrom divides the principles into constitutional, collective-choice, and operational rules. For our purposes of understanding local institutions and how the enabling environment might influence local institutions for REDD+, we grouped the principles into the three levels broadly as follows:

- Constitutional level: principle 1 (clearly defined boundaries).

- Collective-choice level: principle 3 (collective choice).

- Operational level: principle 2 (congruence between rules and local conditions), principle 4 (active monitoring), principle 5 (graduated sanctions), and principle 6 (conflict resolution). 
Table 1. Demographics and information for communities interviewed in this research. Some data are reported categorically to maintain anonymity.

\begin{tabular}{lcccc}
\hline \hline Community & A & B & C & E \\
\hline Year joined Socio Bosque & 2009 & 2009 & 2008 & 2008 \\
Estimated total population & $<400$ & $>5000$ & $400-600$ & $400-600$ \\
Size of conservation area (ha) & $2000-3000$ & $>10,000$ & $2000-3000$ & $<2000$ \\
Incentive per year in 2011 U.S. & $10,000-20,000$ & $30,000-40,000$ & $10,000-20,000$ & $10,000-20,000$ \\
dollars & 20 & 34 & 18 & 22 \\
Structured interviews conducted & 20 & & 18 \\
\hline
\end{tabular}

Source: Adapted from PSB (2011), as cited in Krause et al. (2013).

\section{CASE DESCRIPTION}

We interviewed 94 people in 4 Kichwa communities in the Ecuadorian Amazon. It should be noted that some of this interview data has been used previously to evaluate core REDD+ safeguards, identifying concrete areas for program improvement at the local level (Krause et al. 2013). Three of the interviewed communities were single villages with their own legally recognized communal land title and local administrative decision-making structures. The fourth was a federation, consisting of 17 villages within a single communal land title under the federation's name. To maintain continuity with this previous research (Krause et al. 2013), we refer to the three individual communities as A, C, and $\mathrm{E}$, and to the federation as B (Table 1). Community A was the smallest, with fewer than 400 people, and demonstrated the greatest level of prior organization. This community was touted by Socio Bosque as a model community and regularly received visitors to demonstrate the success of the program. Community A was also the only community that had some form of management plan for the conservation area prior to joining Socio Bosque. Federation B was the largest in terms of population, incentives received, and area under conservation by Socio Bosque. Community $\mathrm{C}$ was located in an area heavily affected by oil production and accompanying infrastructure development, and a resulting influx of external actors. Community E had a relatively small population, with around 400 people, and placed high importance on the conservation area because it was the source of the community's water supply, but was being threatened by expanding intensive agriculture production that required high pesticide use.

Community governance consists of a community president and council, who are democratically elected from within the community constituents every one to three years, depending on the community. In accordance with Ecuadorian law, all four communities have a set of internally defined bylaws that regulate the functioning of communal affairs. Decisions that affect the community are discussed and decided upon in general assemblies. Current internal property rights arrangements allocate small sections of community land to member families for personal forest gardens, and/or other forms of farming, and larger sections that retain their natural forest cover to Socio Bosque. In this respect, there is a division of land-use decision-making authority between the family and community levels. Families manage their assigned piece of land for farming and/or any building or home construction.

Any decisions related to the Socio Bosque conservation area, which is not divided between the families, fall under communal decision-making processes. The management of the Socio Bosque incentives also falls under the communal decision-making system. Communities need to present an investment plan every year that has been approved by the assembly, specifying how they will use the incentives, and they are legally required to manage the incentives according to this plan. Our characterization of the interviewed communities applies broadly to the large majority of Kichwa Amazonian communities in Ecuador. The Kichwa are also the largest indigenous group in the Ecuadorian Amazon (Bremner and $\mathrm{Lu}$ 2006), making these results relevant within the larger context of indigenous communities.

\section{Community and interviewee selection}

Purposeful sampling of communities was undertaken according to the length of time enrolled in Socio Bosque and geographic location. We targeted accessible communities in the Ecuadorian Amazon that had been in the program for at least 18 months. Program payments are made every six months, so these communities had received at least three payments. Three of the four communities interviewed were located in the province of Napo (central Ecuadorian Amazon) and one was located in Sucumbíos (northern Ecuadorian Amazon; Fig. 1). Before undertaking interviews, a meeting was held with community leaders to present the objectives of the research and the proposal to conduct interviews. A date was set for a return visit, and the leadership identified a local guide to support the interviewers as they visited community households. Given that some of the interview topics, including income management and governance, were sensitive, and to promote honest responses, the data were treated anonymously.

To assess how local institutions in the 4 communities fared in comparison to Ostrom's design principles, we conducted 94 structured interviews with Kichwa community inhabitants, selected by random sampling from adults over 18 years of age in each community. Interviews were undertaken in Spanish with community inhabitants by the first two authors and two trained assistant interviewers, with initial field supervision by the last author. The first author had spent six years working in the field in the Ecuadorian Amazon. The second author has spent more than 6 months in the field in the Ecuadorian Amazon over 4 years of researching forest management and conservation in the Amazon. Most interviewees spoke Spanish, but in the event that an interviewee did not speak proficient Spanish, the guide or a family member provided translation from Kichwa to Spanish. Of those interviewed, 73 were registered community members (known as socios, meaning partner or member) and 21 were community inhabitants who were not yet formally registered. We 
interviewed 58 men and 36 women. Our primary aim was to have a fairly large share of women represented, although we did not specifically aim for equal gender or "socio/nonsocio" representation groups. The majority of those interviewed identified themselves as small-scale farmers (51\%), unemployed $(18 \%)$, or as taking care of the house $(11 \%)$, indicating a relatively high degree of socioeconomic homogeneity. For a detailed demographic analysis of the interview participants, please see Krause et al. (2013).

Fig. 1. Geographic location of the four communities interviewed for this research (red boxes) participating in the forest conservation scheme Programa Socio Bosque in the Ecuadorian provinces of Napo (left) and Sucumbíos (right).

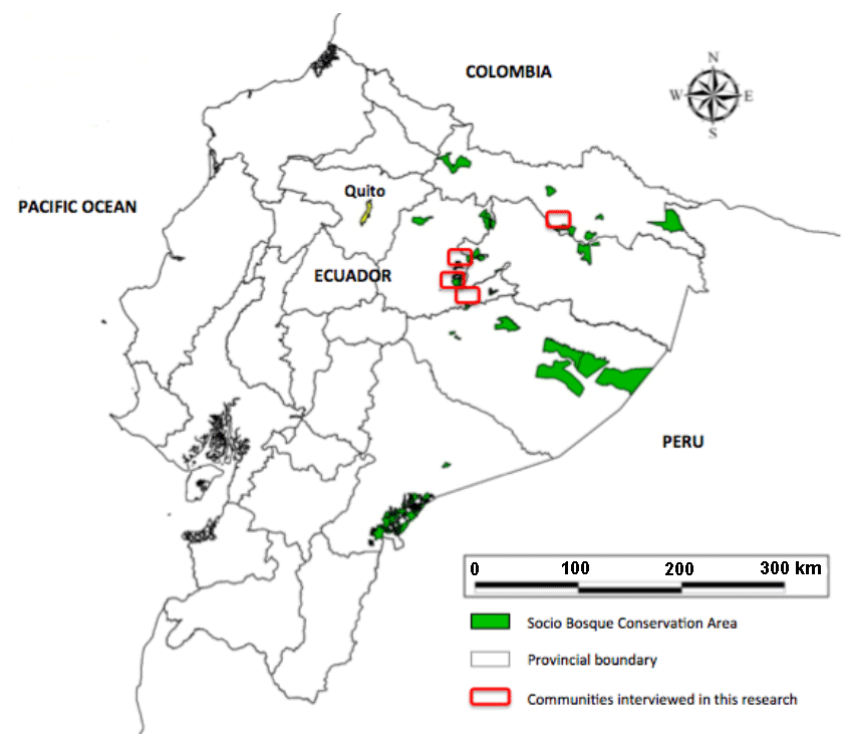

Design and assessment of structured interviews

Using Ostrom's (1990) principles, we created 12 measures (Table 2, Fig. 2) to evaluate institutional performance, assessed on the sum of individual interview responses. In some cases, one measure was used to assess the principle (e.g., measure 8 to assess active monitoring). In other cases, several measures were used for a single principle (e.g., measures 2 and 3 were used to assess clearly defined boundaries for the resource system). This was determined by both the ability to gauge if a principle was met by a certain measure and also by the ease of constructing and assessing certain measures.

We used the data from the interviews to assess community institutions in terms of Ostrom's first six principles. To facilitate analysis, we broadly classified local institutional performance for each measure into two categories: less than $50 \%$, indicating challenges with performance, and $50 \%$ or more, indicating stronger performance. We recognize that this is a subjective division, which may obscure competing interests between different factions. Nevertheless, we think that if fewer than $50 \%$ of the interviewees reported compliance, it is fair to say that this indicates challenges with a set of principles reflecting collective action, which requires a coordinated effort by the majority toward a shared goal. We also recognize that such a division does not identify potentially important differences in the identity of the community members who agree or disagree with the principles, but we have explored this elsewhere (Krause et al. 2013), and believe it is not part of the scope of this paper.

Fig. 2. Visual representation of responses from structured interviews in the four communities as measures for each of the first six of Ostrom's (1990) institutional design principles. Principle 1 represents the constitutional level; principle 3 represents the collective-choice level; and principles 2, 4, 5, and 6 represent the operational level. Measures (left) for each principle (right) are listed in Table 2, representing percent agreement with the measure within each community. Measures between $50 \%$ and $100 \%$ agreement (to the right of the vertical dashed line) indicate stronger institutional performance, and measures between $49 \%$ and $0 \%$ (to the left of the vertical dashed line) indicate weaker institutional performance. Measures 1 and 10 were yes/no questions (marked with *), and are reported here as $100 \% / 0 \%$.

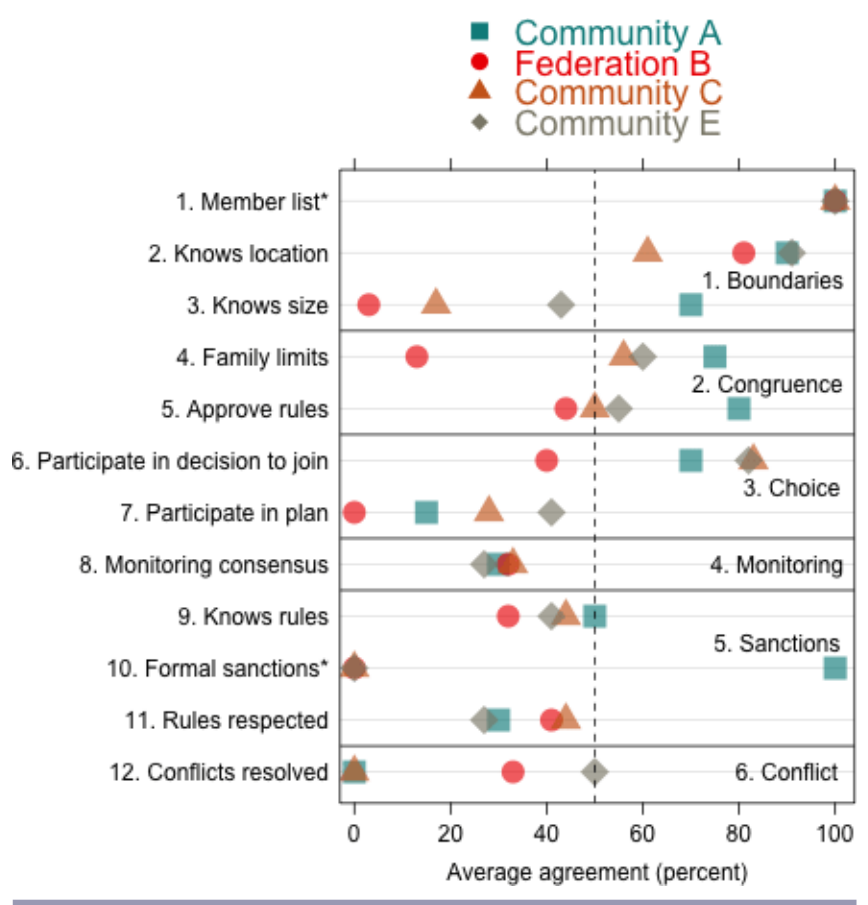

\section{FINDINGS}

Local institutions: participation in Socio Bosque

Design principle 1: clearly defined boundaries for users and for the resource system

As a first measure of this principle, we identified whether communities had formal membership lists (yes/no interview question; measure 1, Table 2). All the communities have legally registered membership lists, and members own the community territory collectively. Members are entitled to all the benefits that being a community member implies, such as a piece of land for personal use, being elected to the community leadership, voting rights on collective issues, and benefit from the Socio Bosque incentives. Thus, all four communities demonstrated strong performance regarding clearly defined boundaries for users. 
Table 2. The 6 design principles for sustainable common pool resource management from Ostrom (1990) assessed by 94 structured interviews in 4 indigenous communities in Ecuador $(n=20$ in community A, 34 in federation B, 18 in community $C$, and 22 in community E).$^{\dagger}$

\begin{tabular}{|c|c|c|c|c|c|c|c|c|}
\hline \multirow[t]{2}{*}{ Design Principle } & \multirow[t]{2}{*}{ Level } & \multirow[t]{2}{*}{$\begin{array}{l}\text { Application to CPR } \\
\text { Management }\end{array}$} & \multirow[t]{2}{*}{ Question to Participants } & \multirow{2}{*}{$\begin{array}{l}\text { Measure Number, Description, } \\
\text { and (Abbreviation Used in } \\
\text { Figure 2) }\end{array}$} & \multicolumn{4}{|c|}{$\begin{array}{l}\text { Community or } \\
\text { Federation }\end{array}$} \\
\hline & & & & & A & $\mathrm{B}$ & $\mathrm{C}$ & $\mathrm{E}$ \\
\hline \multirow[t]{3}{*}{$\begin{array}{l}\text { 1: Clearly defined } \\
\text { boundaries }\end{array}$} & Constitutional & $\begin{array}{l}\text { For users: Individuals } \\
\text { who have rights to } \\
\text { benefit from the CPR } \\
\text { must be clearly } \\
\text { defined. }\end{array}$ & $\begin{array}{l}\text { Is there an updated and clearly } \\
\text { defined membership list for the } \\
\text { community? }\end{array}$ & $\begin{array}{l}\text { 1. Community membership list } \\
\text { exists (member list) }\end{array}$ & Yes & Yes & Yes & Yes \\
\hline & & $\begin{array}{l}\text { For the resource } \\
\text { system: Boundaries of } \\
\text { the CPR system itself } \\
\text { are clearly defined. }\end{array}$ & $\begin{array}{l}\text { Where is the Socio Bosque } \\
\text { conservation area located? }\end{array}$ & $\begin{array}{l}\text { 2. Knowledge of location of } \\
\text { conservation area (knows } \\
\text { location) }\end{array}$ & 90 & 81 & 61 & 91 \\
\hline & & & $\begin{array}{l}\text { Do you know roughly how many } \\
\text { hectares the Socio Bosque } \\
\text { conservation area is? }\end{array}$ & $\begin{array}{l}\text { 3. Knowledge of rough size of } \\
\text { conservation area (knows size) }\end{array}$ & 70 & 3 & 17 & 43 \\
\hline \multirow[t]{2}{*}{ 2: Congruence } & Operational & $\begin{array}{l}\text { Between costs and } \\
\text { benefits: Distribution } \\
\text { of costs and benefits } \\
\text { of CPR management } \\
\text { is fair. }\end{array}$ & $\begin{array}{l}\text { Does participating in Socio Bosque } \\
\text { place limits on your family's } \\
\text { activities? If yes: Has your family } \\
\text { received any benefit from } \\
\text { participating in Socio Bosque? }\end{array}$ & $\begin{array}{l}\text { 4. Interviewees stating } \\
\text { limitations on the family level } \\
\text { from Socio Bosque, who also } \\
\text { perceive family level benefits } \\
\text { from Socio Bosque (family } \\
\text { limits) }\end{array}$ & 75 & 13 & 56 & 60 \\
\hline & & $\begin{array}{l}\text { Between local } \\
\text { conditions and rules: } \\
\text { Conservation rules } \\
\text { are well suited to local } \\
\text { conditions }\end{array}$ & $\begin{array}{l}\text { Do you agree with the Socio Bosque } \\
\text { rules? }\end{array}$ & $\begin{array}{l}\text { 5. Approval of Socio Bosque } \\
\text { conservation rules (approve } \\
\text { rules) }\end{array}$ & 80 & 44 & 50 & 55 \\
\hline \multirow[t]{2}{*}{$\begin{array}{l}\text { 3: Collective-choice } \\
\text { arrangements }\end{array}$} & $\begin{array}{l}\text { Collective- } \\
\text { choice }\end{array}$ & $\begin{array}{l}\text { Most individuals } \\
\text { affected by the rules } \\
\text { participate in making } \\
\text { and modifying these } \\
\text { rules. }\end{array}$ & $\begin{array}{l}\text { Did you participate in the original } \\
\text { decision to join Socio Bosque? }\end{array}$ & $\begin{array}{l}\text { 6. Decision to join Socio } \\
\text { Bosque (participate in decision } \\
\text { to join) }\end{array}$ & 70 & 40 & 83 & 82 \\
\hline & & & $\begin{array}{l}\text { Did you participate in deciding what } \\
\text { to include in the community } \\
\text { investment plan? }\end{array}$ & $\begin{array}{l}\text { 7. Investment plan } \\
\text { participation (participate in } \\
\text { plan) }\end{array}$ & 15 & 0 & 28 & 41 \\
\hline 4: Active monitoring & Operational & $\begin{array}{l}\text { Active monitors are } \\
\text { accountable to the } \\
\text { users or are the users. }\end{array}$ & $\begin{array}{l}\text { How is monitoring of the Socio } \\
\text { Bosque area undertaken in your } \\
\text { community? }\end{array}$ & $\begin{array}{l}\text { 8. Consensus between } \\
\text { interviewees on the most } \\
\text { common monitoring practices } \\
\text { in place (monitoring consensus) }\end{array}$ & 30 & 32 & 33 & 27 \\
\hline \multirow[t]{3}{*}{$\begin{array}{l}\text { 5: Graduated } \\
\text { sanctions }\end{array}$} & Operational & $\begin{array}{l}\text { Users who violate } \\
\text { operational rules are } \\
\text { likely to be given } \\
\text { graduated sanctions } \\
\text { by other users. }\end{array}$ & $\begin{array}{l}\text { What are the rules for the Socio } \\
\text { Bosque conservation area? }\end{array}$ & $\begin{array}{l}\text { 9. Correctly identify rules } \\
\text { (knows rules) }\end{array}$ & 50 & 32 & 44 & 41 \\
\hline & & & $\begin{array}{l}\text { Does the community have formal } \\
\text { sanctions for noncompliance in } \\
\text { place? }\end{array}$ & $\begin{array}{l}\text { 10. Formal sanctions are in } \\
\text { place (formal sanctions) }\end{array}$ & Yes & No & No & No \\
\hline & & & $\begin{array}{l}\text { How often are Socio Bosque } \\
\text { conservation rules respected by the } \\
\text { families? (Closed question: never, } \\
\text { sometimes, always) }\end{array}$ & $\begin{array}{l}\text { 11. Rules are always respected } \\
\text { (rules respected) }\end{array}$ & 30 & 41 & 44 & 27 \\
\hline $\begin{array}{l}\text { 6: Conflict resolution } \\
\text { mechanisms }\end{array}$ & Operational & $\begin{array}{l}\text { Users and officials } \\
\text { have rapid access to } \\
\text { low cost local arenas } \\
\text { to resolve conflicts. }\end{array}$ & $\begin{array}{l}\text { Have conflicts in your community } \\
\text { related to Socio Bosque been } \\
\text { resolved? }\end{array}$ & $\begin{array}{l}\text { 12. Conflicts directly related to } \\
\text { Socio Bosque resolved } \\
\text { (conflicts resolved) }\end{array}$ & 0 & 33 & 0 & 50 \\
\hline \multicolumn{9}{|c|}{$\begin{array}{l}\text { In the second column, principles are categorized according to Ostrom's three institutional levels. A brief description of the relationship of the principle to } \\
\text { CPR management is given (for full explanation, please see text). The interview question(s) used to assess each principle are listed, along with the measure used } \\
\text { to report the answer to each question for each community (See Fig. 2). Results are reported as the percentage of respondents in each community reporting } \\
\text { compliance with a measure identified for each interview question, or for closed questions (marked with a }{ }^{*} \text { ), the yes/no response. } \\
\text { CPR indicates common pool resource. }\end{array}$} \\
\hline
\end{tabular}


To assess clearly defined boundaries for the resource system, we identified two measures. We asked interviewees if they knew, firstly, where the Socio Bosque area was located (measure 2) and, secondly, what the rough size of the area was (measure 3 ). This is a relevant measure because Socio Bosque payments are calculated directly according to the number of hectares the community collectively decides to include in the program. In community A, the majority of community members knew both the location and rough size of the conservation area, demonstrating strong performance for both measures. The majority in communities $\mathrm{C}$ and $\mathrm{E}$ and federation $\mathrm{B}$ knew the general location, but only a minority knew the rough size (Table 2, Fig. 2), displaying mixed performance for clearly defined boundaries.

\section{Design principle 2: congruence between costs and benefits and between conservation rules and local social and governance conditions}

To determine whether there was congruence between how Socio Bosque costs and benefits were distributed at the family level, measure 4 looked at the percentage of interviewees stating that their family experienced limitations from Socio Bosque, but also perceived benefits from Socio Bosque. This measure would determine if the program were reaching the right resource users in allocating its benefits.

Community A performed best, with $75 \%$ of those that did feel limited by participation in Socio Bosque also stating some form of family benefit. In community E, $60 \%$ of those that felt limited also perceived a benefit from Socio Bosque. In community $\mathrm{C}$, the comparable percentage was $56 \%$, and federation $\mathrm{B}$ performed most poorly, with only $13 \%$.

Measure 5 assessed the degree of local approval of the Socio Bosque conservation rules. If there was broad approval of the rules in place, that would indicate that the rules were more congruent with local conditions. In community A there was strong approval of the rules: $80 \%$. In community $\mathrm{E}$ and community $\mathrm{C}$, $55 \%$ and $50 \%$ of interviewees, respectively, approved of the rules in place. In federation B, $44 \%$ approved of the rules. Federation $\mathrm{B}$ was the only community with minority approval levels for this measure.

\section{Design principle 3: collective-choice arrangements}

We identified two measures centered on participation for the collective-choice principle (measures 6-7 in Table 2). Three communities had strong majority participation in the original decision to join Socio Bosque $(70 \%$ or higher for measure 6$)$, federation $\mathrm{B}$ being the exception, where a minority of $40 \%$ participated. However, in all four communities, a minority of those interviewed participated in the process of deciding what to include in the community investment plan (measure 7). This is relevant because assembly review and approval of the Socio Bosque investment plan is a formal program requirement.

\section{Design principle 4: active monitoring}

To assess this principle, measure 8 examined the level of consensus between interviewees regarding monitoring practices in place. A high level of consensus about how monitoring takes place would indicate that some sort of well-understood, standardized monitoring practice was in place, and that monitors reported back regularly to the community. However, our findings in all four communities show no uniformity in the responses, suggesting that community members did not know if or how the conservation forest is monitored. For example, in community A, the most common reply, by six people (30\%; Table 2, Fig. 2), was that community members undertook monitoring themselves. Another two people said there was one forest guard, three people said monitoring was done by leaders, another three stated there was no monitoring in place, three stated that monitoring was done by government officials, and three people did not know if there was monitoring at all. A similar lack of consensus was identified in the other three communities (Table 2 and Fig. 2).

\section{Design principle 5: graduated sanctions}

To assess this principle, measure 9 firstly examined the degree to which respondents were able to correctly identify the rules in place for Socio Bosque. If respondents were unable to identify the rules in place, this would present clear challenges for establishing compliance measures for those rules. Following on this, measure 10 identifies whether the community had a formal set of compliance sanctions in place. Finally, measure 11 examined the degree to which the Socio Bosque rules are respected, as perceived by interviewees. In three communities, fewer than $45 \%$ of respondents knew what the rules were. Community A was the exception, where $50 \%$ knew what the Socio Bosque rules were. Similarly, for the second measure, only community A had a formal set of sanctions in place. In all four communities, fewer than $45 \%$ of the respondents stated that the conservation area is always respected, suggesting that noncompliance with the rules is not uncommon. In summary, in all the communities, except community A, only a minority had knowledge about the rules, and they had no sanctions in place.

Design principle 6: conflict resolution mechanisms

To assess this principle, measure 12 examined whether communities are resolving conflicts directly related to Socio Bosque. The most commonly identified conflict, repeatedly expressed by interviewees and affecting all four communities, was related to income management. Interviewees also reported landuse restrictions and territorial conflicts in community $\mathrm{E}$ and federation $\mathrm{B}$, and noncompliance conflicts in communities $\mathrm{A}$ and $\mathrm{C}$ and federation $\mathrm{B}$. Our interview results show that community E had resolved 1 of 2 conflicts $(50 \%)$, community A had resolved 0 of $2(0 \%)$, community $C$ had resolved 0 of $3(0 \%)$, and federation $\mathrm{B}$ had resolved 1 of $3(33 \%)$. We acknowledge that some of these conflicts may have occurred recently, and there may not have been much time to resolve them.

\section{DISCUSSION}

\section{Local institutions in Socio Bosque}

Based on our results, we found that there was substantial variation between communities with regards to how they fare in relation to Ostrom's (1990) principles (Table 2, Fig. 2). Community A performed strongly ( $50 \%$ or more) on 8 out of 12 measures, with all measures above $50 \%$ for principles 1 (clearly defined boundaries) and 2 (congruence). Federation B performed most poorly, with strong performance on only 2 out of 12 measures. Overall, none of the communities performed well for the principles of collective-choice arrangements (with the exception of the original decision to join the program, i.e., measure 6 , on which three communities performed strongly), active monitoring, graduated sanctions, or conflict resolution mechanisms. Despite 
important indicators of success on the macro level for Socio Bosque (de Koning et al. 2011, Reed 2011, Krause and Loft 2013), our findings suggest that challenges exist at the local institutional level that could hinder the program's long-term sustainability.

In line with previous research, we found that some communities have difficulties developing the institutions shown to be beneficial for sustainable community forest management (Ambika and Ganesh 2006, Chhatre and Agrawal 2008). In our research, this was most notable for the measures directly arising from participation in Socio Bosque. For example, the studied communities have not yet established collective-choice arrangements that ensure that most individuals participate in the Socio Bosque investment plan (measure 7). Although 100\% participation is likely unreasonable, under Ostrom's theory establishing collective action with broad participation is a cornerstone of sustainable CPR management. Therefore, it is important that a majority of individuals participate. We also found quite low levels of community knowledge of Socio Bosque rules (measure 9). This is problematic because active local participation in forest governance has been shown to be a key determinant of positive outcomes in community forest management projects (Agrawal and Ostrom 2001, Persha et al. 2011). Without institutional arrangements that ensure strong majority participation, new conservation and financial management rules may face legitimacy and implementation challenges.

Furthermore, our results showed that some communities are having difficulties distributing the costs and benefits of participation in Socio Bosque fairly. Only in community A did more than two-thirds of the interviewees who stated that Socio Bosque imposes costs for their family also report that they receive some family-level benefit from the program (measure 4). The misalignment of costs and benefits at the local level could undermine the incentive-for-conservation model that Socio Bosque is built upon. In line with CPR theory (Ostrom 1990), the high proportion of individuals who do not see family-level benefits from conserving considerable areas of their collective territory are more likely to be tempted to break Socio Bosque conservation rules.

We identified broad challenges with the principles related to forest conservation on an operational level in all four communities, including monitoring (principle 4), graduated sanctions (principle 5), and conflict resolution mechanisms (principle 6), areas in which none of the community institutions performed well, with the partial exception of community $\mathrm{A}$, who had sanctions in place (measure 10). It can be reasonably predicted that unresolved local conflicts around the operational issues of compliance could erode program legitimacy and limit conditions for building trust and cooperation for Socio Bosque over time.

This is not to say that these communities are unorganized. Rather, our results suggest that local institutions are not yet adapting to effectively deal with the more sophisticated community forest conservation rights and responsibilities arising from participation in Socio Bosque. For example, communities performed better on those measures that reflect constitutional governance issues and very early program decision making (principles 1 and 2, measure 6). Prior to Socio Bosque, all four communities had successfully registered legal deeds to their land, indicating an important degree of existing organizational capacity, which many other communities in Ecuador have not yet achieved. Additionally, our studied communities have basic democratic governance institutions, i.e., bylaws, assemblies, and elected leaders, for dealing with traditional community, territory, and internal land management issues.

However, by participating in Socio Bosque, communities now have new responsibilities, including the collective implementation and enforcement of more rigorous conservation rules, and equitable distribution of newly introduced income from conservation. The identified problems with adapting institutions for collective action are in line with North's (1990) description of institutional development. North stated that significant challenges exist for rural societies to develop new institutions to suit changing conditions at the speed at which they are required. This is relevant for tropical forests and programs like Socio Bosque and REDD+, because change in the commons is poorly understood (Klooster 2000).

If communities that own territories collectively do not develop institutions that coordinate local actions toward a new shared goal, this will present challenges to a conservation objective that requires compliance by most community members. The situation is comparable to that of some other policies and programs for natural resource management that are based on the premise that local populations will transition their behavior accordingly to pursue program goals (Meinzen-Dick et al. 2004), but underestimate the difficulties of doing so. In summary, we speculate that developing local institutions that can support Socio Bosque objectives is important for long-term program success, but this process may involve challenges. This is also consistent with emerging empirical literature on REDD+ REDD-iness processes, which highlights strong path dependency and thus challenges for communities to adjust from the land-use status quo (Agung et al. 2014, Alemagi et al. 2014).

\section{Building local institutions for REDD+}

Socio Bosque is considered a case for learning in future REDD+ projects (USAID 2012) and underscores some opportunities and challenges for REDD+ policy makers. We propose that building local institutions for REDD+ may benefit from a multilevel institutional model that is nested within the international UNFCCC REDD+ framework, relevant national legislation, and incorporation of local institutional norms and capacity (Fig. 3). Assessing local institutions according to whether they fit into the constitutional, collective-choice or operational level may be a helpful guiding structure to building such a multilevel institutional structure for REDD+ (Fig. 3).

In the following sections, we assume that local-level institutions will fall within the framework established by the UNFCCC REDD + framework and national legislation directly related to REDD+ (Fig. 3, REDD+ enabling environment). Incorporating analytical elements from Bray (2013) and the Mexican ejidos example, we focus and structure the analysis in these sections according to Ostrom's (1990) categorization of local institutions, looking first at the constitutional level, continuing to the collective-choice level, and finishing with the operational level. 
Fig. 3. Multilevel institutional framework proposed for REDD+. The three community-level institutions (green) fit within the REDD+ enabling environment, and the REDD+ enabling environment is supportive of local institutional development on the constitutional, collective-choice, and operational levels. REDD+ indicates Reducing Emissions from Deforestation and Forest Degradation; UNFCCC, United Nations Framework Convention on Climate Change.

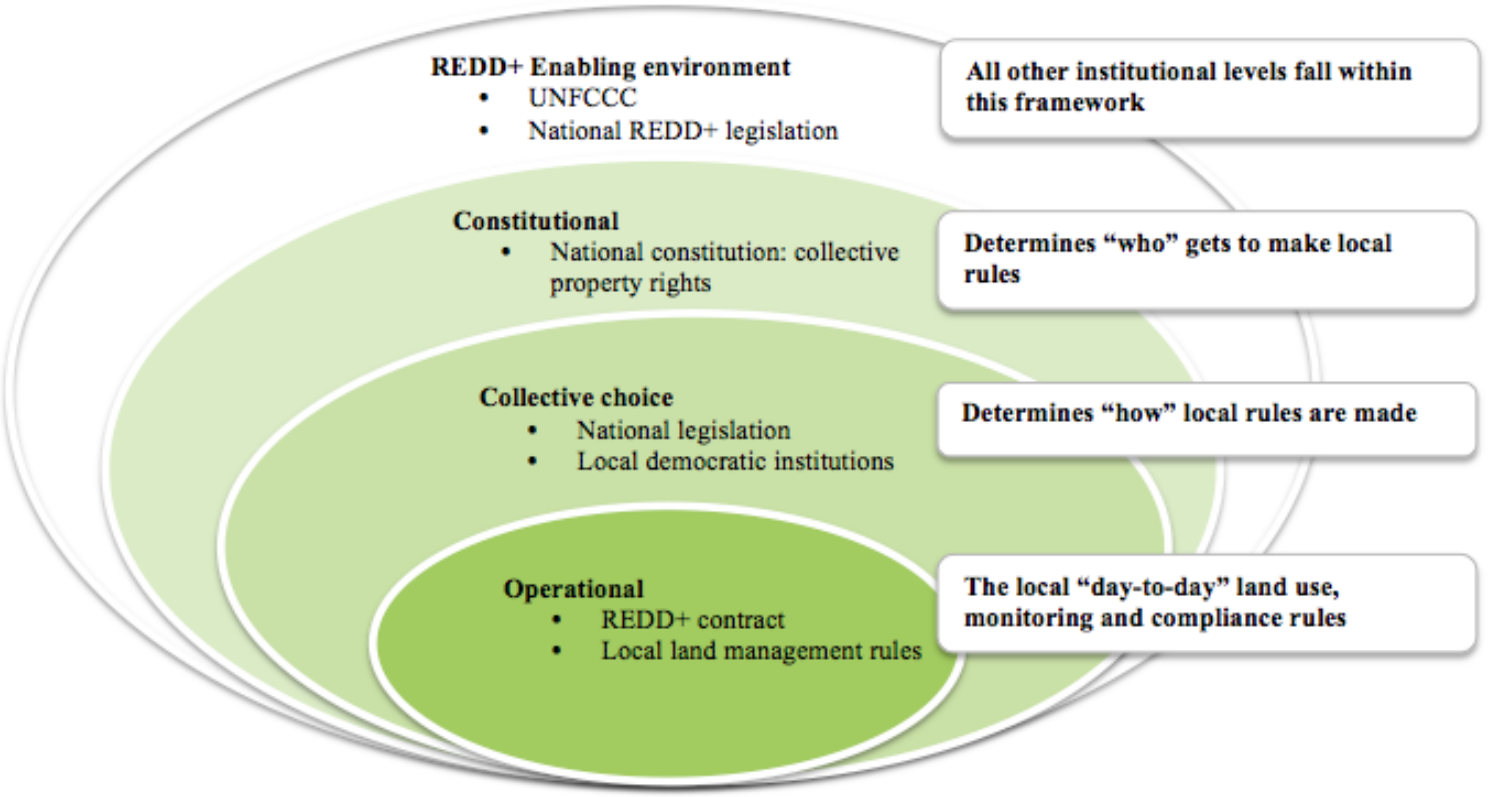

\section{Constitutional rules}

This level refers to who can make the rules and is most relevant to principle 1. As REDD+ in some countries shifts from a projectbased to a jurisdictional approach (Nepstad et al. 2013), in which programs and institutional frameworks operate across entire nations, states, or provinces, experiences like those of Socio Bosque between the national government and indigenous communities to conserve forest commons become more relevant. Within such a context, the external policy environment plays an important role in facilitating or stifling sustainable management of forest commons (Ostrom 1990, Mwangi and Wardell 2012). With much of the Amazon's tropical forest owned or inhabited by indigenous populations, a favorable policy environment is crucial for local organizations to be effective (Swallow et al. 2002).

Our results suggest that the state can be an important promoter of institutional development at the constitutional level by guaranteeing indigenous communities strong property rights and by conditioning these rights to the establishment of clearly defined territorial and user group boundaries (Fig. 3). Ecuador's constitution is progressive in terms of indigenous rights, recognizing and guaranteeing collective property rights, as well as their use, administration, and conservation (Article 57.6). The state defines who can legally own collective property in Ecuador, establishing a platform for constitutional-level institutions over common property forests. In the Socio Bosque case, communities overall performed well on principle 1 (Fig. 2), a constitutionallevel rule that requires clear definition of the user group and the territory, because membership lists were in place and a strong majority knew the conservation area location, if not the size. For nation state-community conservation programs, establishing constitutional-level rules might therefore be embedded in the national constitution, establishing a template for local governance of a delimited territorial property granted to a specified community user group with specific rights (Bray 2013). For largescale contract-based initiatives like jurisdictional REDD + , such top-down measures might be especially useful on the constitutional level, supporting communities in defining who can participate in making and changing rules about how forests are managed toward REDD+ goals.

\section{Collective-choice rules}

This level of rules establishes how those who have been defined as able to make and change rules on the constitutional level can make rules about the territory in question. This level of rules is most relevant to principle 3 (collective-choice arrangements). Our results suggest that the state can have an important role in establishing this institutional level, too. The Ecuadorian Agrarian Law from 1973 defines legislation that establishes basic democratic governance norms for decision making about collectively owned territory (Brassel 2008). A land-owning community is required to establish an assembly composed of all registered members. The assembly elects a president, who is the legal representative, and a treasurer. Through national legislation, the assembly becomes the legally recognized institution for communities to take binding democratic decisions around collective issues. The establishment of a clear requirement for the formation of a community assembly and democratic elections is an important collective-choice institutional precedent in line with self-organization, and is initially defined in Ecuador by national legislation. 
In accord with the Ecuadorian Constitution and the Agrarian Law, Socio Bosque places strong emphasis on the community assembly for decision making and reporting on program issues, and requires collective revenue-spending decisions to be made in the assembly. The Socio Bosque contract introduces a new tool for collective revenue management, the investment plan (PSB 2012a), which the assembly needs to approve. Socio Bosque has also established more detailed reporting procedures that communities need to comply with regarding their investment plan (PSB 2012b). Socio Bosque exerts oversight (as resources permit) to check compliance with these rules. Field technicians, who are responsible for around 18-20 communities each, make periodic visits to review financial reports and verify activities included in the investment plan (MAE 2012). In summary, the community assembly, a legal requirement, is the principal collective-action institution, along with new tools and procedures that Socio Bosque has introduced.

Community performance at the collective-choice level has been more effective in some cases and less so in others. There was strong democratic participation in the original decision to join Socio Bosque in all but federation $\mathrm{B}$, indicating that the assembly was a legitimate forum for approving such a decision. However, participation around Socio Bosque revenue distribution was weaker. This suggests that establishing institutions at the collective-choice level may to some degree be facilitated by policy external to the community; however, there may be certain challenges incorporating new collective-choice rules, in this case around collective revenue distribution. For Amazonian communities, using the assembly as a forum to discuss whether or not to participate in a new program is quite standard practice. In the authors' experience, the assembly in the Ecuadorian Amazon is well recognized as the institution where such a "to participate or not" decision is made. However, it is less clear-cut what the institutional norms for revenue distribution of collectively earned incomes from conservation are, potentially because there is much less experience with this type of collective decision. In most cases, Socio Bosque represents the first time that external funding has been collectively granted to these communities for conservation. Traditionally, most incomes in the Ecuadorian Amazon are private, generated through small-scale agriculture or private employment (MAGAP 2014), and do not require a collective-choice institution to distribute revenues. Ecuador has identified one of Socio Bosque's remaining principal challenges as provision of adequate technical support to communities that enables them to comply with their investment plans (MAE 2015b).

Our results suggest that it may not be a simple matter to insert new collective-choice responsibilities for forest management and revenue distribution, even if a collective-choice institution is in place. Such capacities may need to be developed. This is in line with experiences in Mexico, where nationally defined institutions for common property have entailed a lengthy process over many decades to become established (Bray 2013). A further consideration may be that collective-choice institutions regarding money, defined currently by national law and the Socio Bosque contract, need to be supplemented by local-level institutions to effectively adapt to local conditions. Ideally compliance could be dealt with locally, rather than through program field technicians. For example, community microlending groups have become quite popular in the Ecuadorian Amazon, and there may be local lessons from these groups that can strengthen Socio Bosque incentive management from below. For REDD+, this highlights concerns that whereas countries may make important commitments up-front to developing well-governed REDD+ programs, relatively few readiness proposals are well prepared in terms of establishing mechanisms to coordinate with local institutions, including congruence between costs and benefits (principle 2) and conflict resolution (principle 6; Williams 2013).

\section{Operational-level rules}

This level of rules refers to day-to-day appropriation, provision, restriction, monitoring, and enforcement, and is directly relevant to principles 4 (active monitoring), 5 (graduated sanctions), and 6 (conflict resolution), and less directly to principle 2 (congruence). We found the majority of the challenges in terms of local institutional performance regarding Ostrom's principles at this level. None of the communities performed strongly on the principles of active monitoring and conflict resolution, and only community A had sanctions in place. However, with the exception of federation $\mathrm{B}$, the other three communities did perform relatively well on the principle of congruence; community A again performed best out of the four communities.

Both the national constitution and the Socio Bosque code of practice make reference to operational-level rules, although in differing degrees of detail. The Ecuadorian Constitution guarantees community rights to conserve and promote their own management practices for their surrounding environment and its biodiversity (Article 57.8). The Socio Bosque contract is more specific, prohibiting deforestation, burning, vegetation cover change, commercial hunting, and cattle farming. Socio Bosque makes broad reference to monitoring practices by stating that communities need to clearly delimit the conservation area with signs, report any fires in the conservation area within five days, and provide a report every two years on the state of the conservation area. Socio Bosque applies compliance mechanisms if communities repeatedly do not comply with the terms of the contract, but there is no reference to local compliance mechanisms. These conservation and financial management rules are agreed to by participating communities when they sign the contract. Our results for principle 2 also indicate that $50 \%$ or more of community members in three communities approve of the rules. However, we saw that implementing these rules, or converting them to working rules, presents challenges in practice, despite Socio Bosque having very clearly established rules in the contract. This could be relevant for REDD+ outcomes, because it is essentially these day-to-day operational rules that will operationalize the move away from deforesting land-use practices.

There are two characteristics of operational rules that we can speculate on to explain the challenges with this institutional level. Firstly, this set of operational rules is very new for three of the communities, the exception being community $\mathrm{A}$, which had already established some conservation rules in their management plan. The communities in our study performed more poorly regarding the measures relating to new institutions: namely, revenue distribution at the collective-choice level and most of the operational-level principles. This is in contrast to the institutions related to principles 1 and 2 on boundaries and congruence, and 
measure 6 on choice in the decision to join the program, which were better established and had better community performance. Policy makers for REDD+ will accordingly benefit from understanding that the institutions required at this level for REDD+ to regulate day-to-day resource use may be much newer, and that there is work to be done after these rules have been defined to support communities in developing supporting institutions.

Secondly, operational-level rules rely on execution and compliance from local individuals and families. This is in contrast to constitutional-level and collective-choice-level rules, which are made and executed at the community level and which may be easier to implement and oversee. For example, getting a community to draw up a membership list (constitutional level) or to meet twice a year to review spending reports (collective-choice level) may be easier than getting a majority of individuals and families to adjust land-use behavior in terms of their day-to-day economic activities, including limiting resource extraction in certain areas, following other conservation rules, monitoring these rules, and ensuring compliance. This factor could also contribute to a more lengthy process of institutional development. Importantly, these institutions need to influence and regulate family-level behavior for the community good.

For REDD+, it may not be practical or feasible to have exclusively external rule making for day-to-day operations and monitoring of local execution and compliance in difficult-to-access rural areas. For Socio Bosque, an increased field presence and clear rules are likely to have some positive impact on transparency and participation (Krause et al. 2013), but appear to be insufficient (noncompliance is not uncommon) and will be prohibitively expensive to sustain. On the other hand, many rural forestdwelling communities interested in REDD+ will have had little experience managing forests collectively to access external economic incentives, and may not have established these operational-level institutions themselves.

\section{REDD+: Responding to local institutional challenges}

In many cases, this will be the beginning of a learning process for communities as they, rather than just land owners, adapt to a new role in collective resource production, as has been observed with the agrarian communities in Mexico (Bray 2013). Supporting this will also be a learning process for policy makers as they incorporate considerations on collective forest management dynamics.

We believe that a central question REDD+ policy makers will face is how to go about designing policies that combine top-down policy incentives that establish institutions on the constitutional level (principle 1), and to some degree on the collective-action level (principle 3), with incentives and support that also foster institutional innovations at the operational level (principles 2, 4, 5 , and 6) from the bottom up. We speculate that part of the answer may be in learning from communities that have had more experience building operational-level institutions and linking these to national-level conservation programs. For example, community A performed best in our analysis and was also the only community that had established an internal management plan prior to joining Socio Bosque. In contrast, none of the other communities had undertaken land-management plans, which we speculate was a factor that led to their weaker performance relative to community A in terms of Ostrom's principles.
REDD+ policy makers might respond proactively to local institutional challenges by promoting bottom-up landmanagement planning that addresses community territory as a broader mix of production, conservation, and household mosaics. In this manner REDD+ may be nested into larger community land-management processes, where operational-level institutional development is under way or at least initiated in parallel. In practice, this requires coupling new REDD+ incentives and policies with adequate extension services that support land-management planning and implementation as a necessary element for successful outcomes.

Two implications go hand in hand with prioritizing local institutional capacity building. Firstly, it will require up-front investment in adequate extension support that REDD+ budgets will need to take into consideration. This investment may be resisted by certain decision makers, who might see funding better allocated to other priority areas. However, if local institutional capacity is not prioritized, there is a risk that programs will continuously struggle with problems arising from local communities ill equipped to effectively participate in REDD+.

Secondly, a lasting solution will not be a quick fix and will require a meaningful process of institutional development, rather than a few workshops early on to write a management plan or manage the accounts. In the Ecuadorian Amazon, there is a pertinent saying heard regularly, "El papel aguanta todo,"loosely translated as "Anything can be written on a piece of paper." This captures the difference between writing agreements and rules and actually turning them into working rules, as we propose is necessary for REDD+ to achieve long-term climate change mitigation. Although we speculate that a land management plan has strengthened community A's institutions, community A also performed quite poorly regarding some of Ostrom's principles, notably on some measures for collective-choice arrangements, active monitoring, and conflict resolution mechanisms. In Mexico, communities have had decades of experimentation with the constitutional and collective-choice governance platform to design innovative operational institutions that support community forest enterprise (Bray 2013). Some have been successful in building horizontal production networks such as the intercommunity forest organization in the state of Oaxaca (Klooster 2000). This has taken time, but by prioritizing local institutional development, policy makers are taking a long-term financial sustainability perspective through locally managed forests.

This prioritization is in line with Ostrom (1990), who argues for multifactor systems that support locally established community rules within, and not in conflict with, a set of high-level rules and objectives at larger scales (e.g., the national constitution, Socio Bosque, or REDD+). More contemporary investigation similarly identifies that REDD+ must be designed to systematically and formally link national policy reforms with regional and local forest conservation efforts led by forest users (Kashwan and Holahan 2014; Fig. 3). Establishing conditions for communities to build at least some of their own rules (in this case through a management plan) is in itself a powerful motivator to incentivize communities to regulate their participation through downward accountability rather than participation being overseen by external actors in REDD+. In fact, it might be argued that the full and effective participation of local communities essentially 
implies their ability to influence and strengthen program design and implementation. From this perspective, REDD+ program developers can best facilitate sustainable forest management by establishing an enabling environment that is aware of its reach, and where necessary, supports and is responsive to local institutional development for conservation.

\section{CONCLUSIONS}

Our results show that more attention needs to be given to locallevel processes to effectively implement REDD+. In this study, many of the present communal institutions guiding the participation of the four communities in Socio Bosque are underdeveloped. For rural communities, entering into new conservation agreements with the state implies significant changes and resulting institutional challenges to adjust land-use practices in line with sustainability goals. They will in many cases need to adapt existing institutions and develop new ones that harness individual land-use toward program goals collectively.

As a jurisdictional REDD+ approach becomes more attractive to certain countries and donors, a top-down policy approach can establish an institutional platform that supports communities on the constitutional and collective-action levels. However, a strictly top-down approach may encounter challenges at the land-user level, where the implementation and compliance of new day-today operational rules could be beyond the reach of policy makers and program officials. Policy makers, who are also involved in a learning process, can benefit from being aware of the limits of top-down policy making at this level. By complementing topdown policy measures with incentives for bottom-up institutional development, REDD+ could provide a stronger platform for the full and effective participation of indigenous communities in line with program goals. Accordingly, flexible and continuous support for local communities in developing robust local institutions will be necessary to achieve the bottom-up participation that will underlie successful implementation of conservation policies initiated from the top.

Responses to this article can be read online at: http://www.ecologyandsociety.org/issues/responses. $\mathrm{php} / 8156$

\section{Acknowledgments:}

We are grateful to all the people in the communities who took the time and made the effort to participate in the interviews, making this research possible. The final version of this paper benefited greatly from three anonymous reviewers who provided insightful and generous comments. We acknowledge funding for field research from The Lund University Initiative on Legal Empowerment of the Poor, and for open access publication received through the OPERAs Project (EC-308393) within the European Commission's 7th Framework Programme, Lund University, and the International Institute for Industrial Environmental Economics (IIIEE).

\section{LITERATURE CITED}

Agrawal, A., and E. Ostrom. 2001. Collective action, property rights, and decentralization in resource use in India and Nepal.
Politics \& Society 29:485-514. http://dx.doi.org/10.1177/003232$\underline{9201029004002}$

Agung, P., G. Galudra, M. Van Noordwijk, and R. Maryani. 2014. Reform or reversal: the impact of REDD+ readiness on forest governance in Indonesia. Climate Policy 14:748-768. http://dx. doi.org/10.1080/14693062.2014.941317

Alemagi, D., P. A. Minang, M. Feudjio, and L. Duguma. 2014. REDD+ Readiness process in Cameroon: an analysis of multistakeholder perspectives. Climate Policy 14:709-733. http://dx. doi.org/10.1080/14693062.2014.905439

Ambika, P. G., and P. S. Ganesh. 2006. Conditions for successful local collective action in forestry: some evidence from the hills of Nepal. Society \& Natural Resources 18:153-171.

Angelsen, A., and M. Brockhaus, editors. 2009. Realising REDD+: national strategy and policy options. Centre for International Forestry Research, Bogor, Indonesia.

Angelsen, A., and S. Wertz-Kanounnikoff. 2008. What are the key design issues for REDD and the criteria for assessing options? Pages 11-21 in A. Angelsen, editor. Moving ahead with REDD: issues, options and implications. Centre for International Forestry Research, Bogor, Indonesia.

Babon, A., and G. Y. Gowae. 2013. The context of REDD+ in Papua New Guinea: drivers, agents, and institutions. Centre for International Forestry Research, Bogor, Indonesia.

Baland, J.-M., and J.-P. Platteau. 2000. Halting degradation of natural resources: is there a role for rural communities? Food and Agriculture Organization of the United Nations, Rome, Italy. http://dx.doi.org/10.1093/0198290616.001.0001

Bertzky, M., C. Ravilious, A. L. Araujo Navas, V. Kapos, D. Carrión, M. Chíu, and B. Dickson. 2010. Carbon, biodiversity and ecosystem services: exploring co-benefits. Ecuador. United Nations Environment Programme-World Conservation Monitoring Center, Cambridge, UK.

Brassel, F., S. Herrera, and M. Laforge. 2008. Reforma agraria en el Ecuador?: viejos temas, nuevos argumentos. Sistema de Investigación Sobre la Problemática Agraria en el Ecuador. Universidad Central del Ecuador, Quito, Ecuador.

Bray, D. B. 2013. When the state supplies the commons: origins, changes, and design of Mexico's common property regime. Journal of Latin American Geography 12:33-55. http://dx.doi. org/10.1353/lag.2013.0003

Bremner, J., and F. Lu. 2006. Common property among indigenous peoples of the Ecuadorian Amazon. Conservation \& Society 4:499-521.

Chhatre, A., and A. Agrawal. 2008. Forest commons and local enforcement. Proceedings of the National Academy of Sciences of the United States of America 105:13286-13291. http://dx.doi. org/10.1073/pnas.0803399105

Cronkleton, P., D. B. Bray, and G. Medina. 2011. Community forest management and the emergence of multi-scale governance institutions: lessons for REDD+ development from Mexico, Brazil and Bolivia. Forests 2011:451-473. http://dx.doi. org/10.3390/f2020451 
Da Fonseca, G. A. B., C. M. Rodriguez, G. Midgley, J. Busch, L. Hannah, and R. A. Mittermeier. 2007. No forest left behind. PLoS Biology 5(8):e216. doi:10.1371/journal.pbio.0050216

De Koning, F., M. Aguiñaga, M. Bravo, M. Chiu, M. Lascano, T. Lozada, and L. Suarez. 2011. Bridging the gap between forest conservation and poverty alleviation: the Ecuadorian Socio Bosque program. Environmental Science \& Policy 14:531-542. http://dx.doi.org/10.1016/j.envsci.2011.04.007.

Dongier, P., J. Van Domelen, E. Ostrom, A. Ryan, W. Wakeman, A. Bebbington, S. Alkire, T. Esmail, and M. Polski. 2003. Community driven development. World Bank Poverty Reduction Strategy Paper. World Bank, Washington, D.C., USA.

Eliasch, J. 2008. Climate change: financing global forests: the Eliasch review. Earthscan, London, UK.

Food and Agriculture Organization of the United Nations (FAO). 2009. State of the world's forests: 2009. Food and Agricultural Organization of the United Nations, Rome, Italy.

Food and Agriculture Organization of the United Nations (FAO). 2011. State of the world's forests: 2011. Food and Agriculture Organization of the United Nations, Rome, Italy.

Grubb, M. 2011. Durban: the darkest hour? Climate Policy 11:1269-1271. http://dx.doi.org/10.1080/14693062.2011.628786

Intergovernmental Panel on Climate Change (IPCC). 2014. Climate change 2014: mitigation of climate change. Working Group III contribution to the Fifth Assessment Report of the Intergovernmental Panel on Climate Change. O. Edenhofer, R. Pichs-Madruga, Y. Sokona, E. Farahani, S. Kadner, K. Seyboth, A. Adler, I. Baum, S. Brunner, P. Eickemeier, B. Kriemann, J. Savolainen, S. Schlömer, C. von Stechow, T. Zwickel, and J. C. Minx, editors. Cambridge University Press, Cambridge, UK. [online] URL: https://www.ipcc.ch/pdf/assessment-report/ar5/ wg3/ipcc wg3 ar5 full.pdf

International Resources Group (IRG). 2010. Evaluacion $e$ inclusion del enfoque de genero y equidad en los planes de inversion del proyecto Socio Bosque. Socio Bosque \& El Ministerio del Ambiente del Ecuador, Quito, Ecuador.

International Tropical Timber Organization (ITTO). 2010. Tropical forest tenure assessment: trends, challenges and opportunities. International Conference on Forest Tenure, Governance \& Enterprise. Yaoundé, Cameroon. Rights and Resources Initiative Washington, D.C., USA, and International Tropical Timber Organization, Yokohama, Japan.

Kashwan, P., and R. Holahan. 2014. Nested governance for effective REDD+: institutional and political arguments. International Journal of the Commons 8:554-575. http://dx.doi. org/10.18352/ijc. 450

Klooster, D. 2000. Institutional choice, community, and struggle: a case study of forest co-management in Mexico. World Development 28:1-20. http://dx.doi.org/10.1016/S0305-750X(99) 00108-4

Krause, T., W. Collen, and K. A. Nicholas. 2013. Evaluating safeguards in a conservation incentive program: participation, consent, and benefit sharing in indigenous communities of the Ecuadorian Amazon. Ecology and Society 18(4):1. http://dx.doi. org/10.5751/es-05733-180401
Krause, T., and L. Loft. 2013. Benefit distribution and equity in Ecuador's Socio Bosque Program. Society \& Natural Resources 26:1170-1184. http://dx.doi.org/10.1080/08941920.2013.797529

Meinzen-Dick, R., M. Digregorio, and N. Mccarthy. 2004. Methods for studying collective action in rural development. Agricultural Systems 82:197-214. http://dx.doi.org/10.1016/j. agsy.2004.07.006

Minang, P. A., M. Van Noordwijk, L. A. Duguma, D. Alemagi, T. H. Do, F. Bernard, P. Agung, V. Robiglio, D. Catacutan, S. Suyanto, et al. 2014. REDD+ readiness progress across countries: time for reconsideration. Climate Policy 14:685-708. http://dx.doi. org/10.1080/14693062.2014.905822

Ministerio de Agricultura Ganadería, Acuacultura y Pesca (MAGAP). 2014. Reconversión agroproductiva sostenible en la Amazonía Ecuatoriana. MAGAP, Quito, Ecuador.

Ministerio del Medio Ambiente Del Ecuador (MAE). 2009. Manual operative del Proyecto Socio Bosque. Acuerdo No. 15. Ministry of Environment of Ecuador, Quito, Ecuador.

Ministerio del Medio Ambiente Del Ecuador (MAE). 2011. Estimación de la taza de deforestación del Ecuador continental. Ministry of Environment of Ecuador, Quito, Ecuador.

Ministerio del Medio Ambiente Del Ecuador (MAE). 2012. Manual operativo unificado. Proyecto Socio Bosque. Ministry of Environment of Ecuador, Quito, Ecuador.

Ministerio del Medio Ambiente Del Ecuador (MAE). $2013 a$. Acuerdo ministerial No. 33. Ministry of Environment of Ecuador, Quito, Ecuador.

Ministerio del Medio Ambiente Del Ecuador (MAE). $2013 b$. Acuerdo ministerial No. 128. Ministry of Environment of Ecuador, Quito, Ecuador.

Ministerio del Medio Ambiente Del Ecuador(MAE). 2014a. Guia de requisitos y procedimientos del sistema de registro $R E D D$. Ministry of Environment of Ecuador, Quito, Ecuador.

Ministerio del Medio Ambiente del Ecuador (MAE). $2014 b$. Resultados de Socio Bosque Ministry of Environment of Ecuador, Quito, Ecuador. [online] URL: http://sociobosque.ambiente.gob. ec/node/44

Ministerio del Medio Ambiente Del Ecuador (MAE). 2015a. Hectáreas por beneficiaries 2015. Ministry of Environment of Ecuador, Quito, Ecuador. [online] URL: http://sociobosque. ambiente.gob.ec/?q=node/ 330

Ministerio del Medio Ambiente del Ecuador (MAE). $2015 b$. Quinto informe nacional para el Convenio sobre la Diversidad Biológica. Ministry of Environment of Ecuador, Quito, Ecuador.

Mosandl, R., S. Günter, B. Stimm, and M. Weber. 2008. Ecuador suffers the highest deforestation rate in South America. Pages 37-40 in E. Beck, J. Bendix, I. Kottke, F. Makeschin, and R. Mosandl, editors. Gradients in a tropical mountain ecosystem of Ecuador. Volume 198 of the series Ecological studies. Springer, Berlin, Germany. http://dx.doi.org/10.1007/978-3-540-73526-7 4

Mwangi, E., and A. Wardell. 2012. Multi-level governance of forest resources. International Journal of the Commons 6:79-103. http://dx.doi.org/10.18352/ijc.374 
Nepstad, D. C., W. Boyd, C. M. Stickler, T. Bezerra, and A. A. Azevedo. 2013. Responding to climate change and the global land crisis: REDD+, market transformation and low-emissions rural development. Philosophical Transactions of the Royal Society B: Biological Sciences 368:20120167. http://dx.doi.org/10.1098/ rstb.2012.0167

North, D. C. 1990. Institutions, institutional change and economic performance. Cambridge University Press, Cambridge, UK. http://dx.doi.org/10.1017/CBO9780511808678

Ostrom, E. 1990. Governing the commons: the evolution of institutions for collective action. Cambridge University Press, Cambridge, UK. http://dx.doi.org/10.1017/CBO9780511807763

Ostrom, E. 1999. Self governance and forest resources. Occasional Paper No. 20. Centre for International Forestry Research, Bogor, Indonesia. http://dx.doi.org/10.17528/cifor/000536

Ostrom, E. 2009. Design principles of robust property-rights institutions: what have we learned? Pages 32-36 in K. G. Ingram and Y.-H. Hong, editors. Property rights and land policies. Lincoln Institute of Land Policy, Cambridge, Massachusetts, USA.

Parker, C., A. Mitchell, M. Trivedi, and N. Mardas. 2009. The little REDD book: a guide to governmental and non-governmental proposals for reducing emissions from deforestation and degradation. Global Canopy Programme, Oxford, UK.

Persha, L., A. Agrawal, and A. Chhatre. 2011. Social and ecological synergy: local rulemaking, forest livelihoods, and biodiversity conservation. Science 331:1606-1608. http://dx.doi. org/10.1126/science.1199343

Pistorius, T. 2012. From RED to REDD+: the evolution of a forest-based mitigation approach for developing countries. Current Opinion in Environmental Sustainability 4:638-645. http:// dx.doi.org/10.1016/j.cosust.2012.07.002

Programa Socio Bosque (PSB). 2012a. Manual para elaborar un plan de inversión de forma participativa. Ministry of Environment of Ecuador, Quito, Ecuador.

Programa Socio Bosque (PSB). 2012b. Manual práctico para la rendición de cuentas del plan de inversión del Programa Socio Bosque. Ministry of Environment of Ecuador, Quito, Ecuador.

Reed, P. 2011. REDD+ and the indigenous question: a case study from Ecuador. Forests 2:525-549. http://dx.doi.org/10.3390/ $\underline{\mathrm{f} 2020525}$

Ricketts, T. H., B. Soares-Filho, G. A. B. Da Fonseca, D. Nepstad, A. Pfaff, A. Petsonk, A. Anderson, D. Boucher, A. Cattaneo, and M. Conte. 2010. indigenous lands, protected areas, and slowing climate change. PLoS Biology 8:e1000331. http://dx.doi. org/10.1371/journal.pbio.1000331

Rojas, C., G. Minango, G. Galarza, R. Gallardo, and J. C. Rojas. 2011.Resultados de la Evaluacion a socios comunitarios. Programa Socio Bosque \& El Ministerio del Medio Ambiente del Ecuador, Quito, Ecuador.

Secretaría Nacional de Planificación y Desarrollo del Ecuador (SENPLADES). 2008. Plan nacional para el buen vivir, 2009-2013. Secretaría Nacional de Planificación y Desarrollo, Quito, Ecuador.
Shankland, A., and L. Hasenclever. 2011. indigenous peoples and the regulation of REDD+ in Brazil: beyond the war of the worlds? IDS Bulletin 42:80-88. http://dx.doi.org/10.1111/j.1759-5436.2011.00225. $\underline{x}$

Skutsch, M., and P. Van Laake. 2008. REDD as multi level governance in-the-making. Energy \& Environment 19:831-844. http://dx.doi.org/10.1260/095830508785363622

Sobrevila, C. 2008. The role of indigenous peoples in biodiversity conservation: the natural but often forgotten partners. World Bank, Washington D.C., USA.

Sunderlin, W., J. Hatcher, and M. Liddle. 2008. From exclusion to ownership? Challenges and opportunities in advancing forest tenure reform. Rights and Resources Initiative, Washington, D.C., USA.

Swallow, B. M., D. P. Garrity, and M. van Noordwijk. 2002. The effects of scales, flows and filters on property rights and collective action in watershed management. Water Policy 3:457-474. http:// dx.doi.org/10.1016/S1366-7017(02)00011-9

United Nations Collaborative Initiative on Reducing Emissions from Deforestation and forest Degradation (UN-REDD). 2012. UN-REDD Programme Social and Environmental Principles and Criteria. UN-REDD Programme Eighth Policy Board Meeting. 25-26 March, 2012. UN-REDD Programme, Asunción, Paraguay.

United States Agency for International Development (USAID). 2012. Forest Carbon, Markets and Communities (FCMC) program. Key findings and opportunities for REDD+ in Ecuador. Tetra Tech ARD. United States Agency for International Development, Burlington, Vermont, USA.

Van Dam, C. 2011. indigenous territories and REDD in Latin America: opportunity or threat? Forests 2:394-414. http://dx.doi. org/10.3390/f2010394

Williams, L. G. 2013. Putting the pieces together for good governance of REDD+: an analysis of 32 REDD+ country readiness proposals. World Resources Institute, Washington D.C., USA. 